\title{
PENERAPAN MODEL PEMBELAJARAN YESUS DALAM MATIUS 7:24-29 TERHADAP HASIL BELAJAR SISWA DI SMPN 12 KOTA KUPANG
}

\author{
Marsi Bombongan Rantesalu \\ Dosen Jurusan Pendidikan Agama Kristen di Institut Agama Kristen Negeri Kupang \\ marsibombongan@gmail.com \\ Hesti Arista Dara \\ Mahasiswa program Pascasarjana di Institut Agama Kristen Negeri Kupang \\ Hestydara16@gmail.com
}

\begin{abstract}
Abstraksi
Penelitian ini menelisik model pembelajaran yang dipakai oleh Yesus ketika berkhotbah atau mengajar khususnya yang terdapat dalam Matius 7:24-29. Ada beberapa metode yang digunakan Yesus pada bagian ini yaitu: metode ceramah, metode bercerita dan metode perumpamaan. Metode-metode tersebut cukup berhasil dalam pengajaran Yesus yang dibuktikan dengan banyaknya pengikut yang takjub terhadapNya. Pada penelitian ini penulis ingin mengetahui bagaimana pengaruh penerapan metode yang digunakan Yesus dalam Matius 7:24-29 terhadap hasil belajar siswa. Metode yang digunakan dalam penelitian ini adalah metode kuantitatif dengan teknik survey. Populasi penelitiannya adalah adalah keseluruhan siswa kelas IX di SMP Negeri 12 Kota Kupang dengan jumlah sampel sebanyak 30 orang siswa. Analisis data dilakukan dengan teknik statistik dengan proses analisa data yaitu Analisis Deskriptif, Uji Persyaratan Analisis dan Uji Hipotesis. Hasil penelitian menunjukkan bahwa penerapan Metode Pembelajaran yang dipakai Yesus Dalam Matius 7:24-29 berpengaruh terhadap hasil belajar Siswa Di SMP Negeri 12 Kota Kupang sebesar $40 \%$.
\end{abstract}

Kata Kunci: Model Pembelajaran, Matius 7:24-29, Hasil Belajar, Siswa, Guru.

\begin{abstract}
This research examines the learning model used by Jesus when preaching or teaching specifically found in Matthew 7: 24-29. There are several methods that Jesus uses in this section, namely: the lecture method, the method of storytelling and the method of parable. These methods were quite successful in Jesus' teaching as evidenced by the large number of followers who were amazed at him. In this study, we want to find out how the influence of the application of the method Jesus used on student learning outcomes. The method used in this study is a quantitative method with survey techniques. The research population was all of the ninth grade students in SMP Negeri 12 Kota Kupang with a total sample of 30 students. Data analysis was performed using statistical techniques with data analysis processes namely Descriptive Analysis, Test Requirements Analysis and Hypothesis Test. The results showed that the application of the Learning Method used by Jesus in Matthew 7: 24-29 had an effect on student learning outcomes at SMP Negeri 12 Kota Kupang by $40 \%$.
\end{abstract}

Keywords: Learning Model, Matthew 7: 24-29, Learning Outcomes, Students, Teachers. 


\section{Pendahuluan}

Dalam pelayanan Tuhan Yesus ketika berada di dunia, Dia meninggalkan banyak teladan yang seharusnya diikuti oleh setiap orang percaya. Salah satu yang disematkan pada diri Yesus adalah Guru yang Agung. Sebagai Guru agung dia mengajar dengan penuh kuasa yang ada pada-Nya. Selain memiliki kuasa yang begitu hebat, Yesus juga dalam mengajar selalu menggunakan beberapa metode untuk membangun kontak dengan pendengar-Nya. Salah satu bagian dalam kitab Injil yang memperlihatkan bagaiman Yesus mengajar dengan menggunakan metode adalah dalam Matius 7:24-29. Bagian ini merupakan akhir dari pengajaran Yesus dalam khotbah di bukit.

Kemampuan Yesus dalam memberikan pengajaran membuat banyak orang takjub sehingga orang banyak Melihat-Nya sebagai sosok seorang yang begitu istimewa. ${ }^{1}$ Sering sekali kita jumpai dalam kitab Injil bagaimana Yesus menggugah kreatifitas orang lain dengan

\footnotetext{
${ }^{1}$ Deflit Dujerslaim Lilo, "Presuposisi dan Metode Yesus dalam Menyampaikan Pendapat: Sebuah Pedoman bagi Para Akademisi," BIA': Jurnal Teologi dan Pendidikan Kristen Kontekstual 2, no. 1 (June 26, 2019): 121-138, accessed May 30, 2020,

http://www.jurnalbia.com/index.php/bia/article/vie w/86.

${ }^{2}$ Wismoady Wahono, Disini Ku Temukan (Jakarta: BPK Gunung Mulia, 2015), 387.
}

cara mengarahkan orang yang bertanya kepada-Nya menemukan sendiri jawaban pertanyaan, dengan membalikkan pertanyaan tersebut kembali kepada si penanya. ${ }^{2} \mathrm{Hal}$ itu merupakan salah strategi yang digunakan-Nya. Dalam mengajar Yesus menggunakan beberapa metode seperti yang terdapat dalam Matius 7:2429. Dalam bagian ini Yesus menyampaikan khotbah-Nya dengan menggunakan metode ceramah, metode bercerita dan menggunakan metode perumpamaan. ${ }^{3}$ Dengan metode ceramah Yesus berusaha menyampaikan pengetahuan kepada murid-muridNya atau menafsirkan pengetahuan tersebut dan dalam Metode perumpamaan ini merupakan cara Yesus menyampaikan pesan yang paling sederhana dan mudah diingat oleh pendengarnya. ${ }^{4}$

Sebagai seorang Guru Pendidikan Agama Kristen (Guru PAK) sepantasnyalah untuk meneladani Yesus sebagai guru yang agung. Seorang guru Agama Kristen dituntut darinya untuk

3 Imanuel Agung and Made Astika, "Penerapan Metode Mengajar Yesus Menurut Injil Sinoptik Dalam Pelaksanaan Pendidikan Agama Kristen Di SMA Gamaliel Makassar," Jurnal Jaffray 9, no. 2 (October 1, 2011): 147-171, accessed May 2020, https://ojs.sttjaffray.ac.id/JJV71/article/view/99.

4 Daniel Nuhamara, Pembimbing PAK (Bandung: Jurnal Info Media, 2007), 137. 
memperlengkapi anak didik dengan berbagai kebutuhan agar bertumbuh di dalam Yesus Kristus. ${ }^{5}$ Guru PAK juga harus meneladani Yesus dalam hal mempelajari karakter setiap peserta didiknya. ${ }^{6}$ Selain itu seorang Guru PAK harus memiliki kemampuan mengajar secara kreatif yang meliputi banyak hal sepertimemiliki sifat yang mencerminkan pengenalan akan Tuhan dan firman-Nya, dia juga harus mampu persiapan pelajaran dengan cara merencanakan isi pelajaran, kemampuan dalam memakai beraneka macam metode mengajar. ${ }^{7}$ Seorang Guru PAK yang mampu meneladani Yesus sebagai guru agung bisa menjadi pelopor perubahan pada peserta didik. ${ }^{8}$

Kenyataan menurut pengamatan dan pengalaman peneliti bahwa cukup banyak guru PAK yang tidak setia menjalankan tugasnya dan lupa akan panggilannya. Ditinjau dari segi kompetensi guru. Banyak guru yang enggan meningkatkan kemampuannya

5 Talizaro Tafonao, "Yesus Sebagai Guru Teladan Dalam Masyarakat Berdasarkan Perspektif Injil Matius," Khazanah Theologia 2, no. 1 (April 30, 2020): 52-60, accessed May 30, 2020 , https://journal.uinsgd.ac.id/index.php/kt/article/vie w/8390.

6 Ronald Yohanes Sinlae, "Kompetensi Pedagogik Tuhan Yesus dalam Injil Matius Pasal 57," Excelsis Deo: Jurnal Teologi, Misiologi, dan Pendidikan 4, no. 1 (December 31, 2019): 35-55, accessed May 30, 2020, http://e- bahkan dapat dikatakan mengalami kemunduran karena kurangnya motivasi untuk menjadi maju dan berkualitas. Hal demikian dapat dilihat dengan adanya guru-guru yang masih melaksanakan pengajaran dengan pola lama dengan bergantung pada satu-dua buku sumber tanpa buku-buku referensi sebagai penunjang. Permasalahan lain adalah banyak kurang memperhatikan persoalan metode mengajar. Metode yang digunakan cenderung tidak mempertimbangkan kebutuhan peserta didik sehingga tujuan untuk mencapai perjumpaan dengan Allah itu tidak tercapai. Selain itu penggunaan metode yang tidak tepat membuat hasil belajar peserta didik yang tidak maksimal.

Dengan dasar keprihatinan atas persoalan diatas penulis kemudian merasa perlu untuk menerapkan apa yang terdapat dalam Injil Matius 7:24-29 sebagai acuan bagi guru PAK dalam melaksanakan tanggung jawabnya. Penulis menganggap Metode yang digunakan Yesus relevan utuk segala masa sehingga penulis

journal.sttexcelsius.ac.id/index.php/excelsisdeo/arti cle/view/15.

7 Janet Kuhns, "Mengajar Secara Kreatif," Jurnal Jaffray 1, no. 1 (January 5, 2005): 90-100, accessed May 30, 2020, https://ojs.sttjaffray.ac.id/JJV71/article/view/171.

8 Marsi Bombongan Rantesalu, GURU PENDIDIKAN AGAMA KRISTEN SEBAGAI PELOPOR REVOLUSI MENTAL, preprint (AgriXiv, October 14, 2019), accessed January 21, 2020, https://osf.io/576qt. 
melakukan penelitian mengenai penerapan metode pembelajaran dalam Injil Matius 7: 24-29 terhadap hasil belajar siswa di SMPN 12 Kota Kupang.

Penelitian terdahulu pernah membahas topik yang sama. Pada penelitian yang dilakukan Dina Kristiani yaitu implementasi model teaching learning Tuhan Yesus menurut Injil Matius terhadap guru-guru Pendidikan Agama Kristen di Kota Surakarta. Kesimpulannya bahwa model teaching learning Tuhan Yesus menurut Injil Matius yang disoroti oleh Matius berdasarkan nilai-nilai kehidupan pribadi-Nya patut diteladani oleh semua guru Pendidikan Agama Kristen (PAK) pada jaman sekarang ini. ${ }^{9}$ Penelitian Imanuel Agung dan Kadek Astika membahas tentang Penerapan Metode Mengajar Yesus Menurut Injil Sinoptik Dalam Pelaksanaan Pendidikan Agama Kristen Di Sma Gamaliel Makassar. Hasilnya menyebutkan bahwa metode mengajar Yesus masih sangat relevan digunakan pada masa kini. Hal ini dapat dilihat dari hasil penelitian yang penulis lakukan di SMA Gamaliel

9 Dina Kristiani, "IMPLEMENTASI MODEL TEACHING LEARNING TUHAN YESUS MENURUT INJIL MATIUS TERHADAP GURU-GURU PENDIDIKAN AGAMA KRISTEN DI KOTA SURAKARTA," REGULA FIDEI: Jurnal Pendidikan Agama Kristen 3, no. 1 (2018): 1-21, accessed May 30, 2020,
Makassar, penulis mendapatkan data bahwa guru PAK di SMA Gamaliel Makassar menggunakan metode-metode mengajar yang Yesus gunakan dan hasilnya cukup signifikan. ${ }^{10}$

Penelitian ini berbeda dengan penelitian-penelitian di atas. Selain perbedaan dari lokasi penelitian beserta populasi dan sampelnya, penelitian ini lebih fokus mencari Pengaruh dari penerapan Metode Pembelajaran Dalam Matius 7:24-29 Terhadap Hasil Belajar Siswa Di SMP Negeri 12 Kota Kupang.

\section{Metode penelitian}

Metode yang digunakan dalam penelitian ini adalah metode kuantitatif karena penelitian ini akan meneliti sampel pada populasi tertentu. Teknik yang digunakan adalah survey. Penelitian dilakukan di SMP Negeri 12 Kota Kupang yang terletak di jalan Oebon I Sikumana, Kelurahan Sikumana, Kec. Maulafa, Kota Kupang Prov. Nusa Tenggara Timur.

Populasi Menurut Sugiyono adalah wilayah generalisasi yang terdiri atas obyek/subyek yang mempunyai kualitas dan karakteristik tertentu yang ditetapkan

http://christianeducation.id/ejournal/index.php/regulafidei/article/view/16.

${ }^{10}$ Agung and Astika, "Penerapan Metode Mengajar Yesus Menurut Injil Sinoptik Dalam Pelaksanaan Pendidikan Agama Kristen Di SMA Gamaliel Makassar." 
oleh peneliti untuk dipelajari kemudian ditarik kesimpulannya. ${ }^{11}$ Dalam penelitian ini populasi adalah keseluruhan siswa/i kelas IX di SMP Negeri 12 Kota Kupang. Jumlah sampel sebanyak 30 orang siswa.
Pengumpulan data di lapangan dilakukan dengan menggunakan kuesioner. Adapun gambaran teknik pengumpulan data untuk setiap variabel dapat dilihat dalam tabel berikut :

Tabel Teknik Pengumpulan Data

\begin{tabular}{|l|l|l|l|l|l|l|}
\hline No & Variabel & $\begin{array}{l}\text { Teknik } \\
\text { pengumpulan } \\
\text { data }\end{array}$ & $\begin{array}{l}\text { Model } \\
\text { Skala }\end{array}$ & $\begin{array}{l}\text { Rentang } \\
\text { Skor }\end{array}$ & $\begin{array}{l}\text { Jenis } \\
\text { Skala } \\
\text { Data }\end{array}$ & $\begin{array}{l}\text { Sumber } \\
\text { Data }\end{array}$ \\
\hline 1. & $\begin{array}{l}\text { Metode } \\
\text { Pembelajaran } \\
\text { Menurut 7:24-29 } \\
\text { X) }\end{array}$ & Angket & Likert & $1-4$ & Interval & Siswa \\
\hline 2. & Hasil Belajar (Y) & \multicolumn{3}{|c|}{ Nilai Ujian Akhir Siswa } & Siswa \\
\hline
\end{tabular}

Instrumen yang digunakan terlebih dahulu dilakukan uji coba dengan Kisi-kisi instrumen untuk variabel (X) Metode Pembelajaran dalam Matius 7:24-29, ditandai dengan indikator : Metode ceramah, metode perumpamaan, dan metode cerita. Adapun penempatan butir untuk setiap indikator dapat dilihat dalam tabel sebagai berikut :

\section{Kisi-Kisi Instrumen}

Metode Pembelajaran Berdasarkan Matius 7:24-29

\begin{tabular}{|l|l|l|}
\hline Variabel X & Indikator & $\begin{array}{l}\text { Nomor Butir } \\
\text { Pertayaan }\end{array}$ \\
\hline \multirow{3}{*}{$\begin{array}{l}\text { Metode } \\
\text { Pembelajaran }\end{array}$} & Metode Ceramah & $1,2,3,4,5,6,7,8,9,10$ \\
\cline { 2 - 3 } & Metode Perumpamaan & $11,12,13,14,15,16,17,18,19,20$ \\
\cline { 2 - 3 } & Metode Cerita & $21,22,23,24,25,26,27,28,29,30$ \\
\hline
\end{tabular}

Sebelum digunakan untuk dan uji rehabilitas. Instrumen yang valid mengumpulkan data penelitian, terlebih dan juga realible merupakan syarat utama dahulu kuesioner sebagai instrumen untuk memperoleh hasil penelitian yang penelitian dikalibrasi dengan uji validitas juga valid dan reliable. Uji validitas

${ }^{11}$ Sugiyono, Metode Penelitian Kombinasi (Bandung: Alfabeta, 2015), 119. 
dilakukan untuk melihat sejauh mana ketepatan dan kecermatan suatu alat ukur/instrumen dalam melakukan fungsi ukurnya. ${ }^{12}$ Kalibrasi instrumen untuk variabel $(\mathrm{X})$ metode pembelajaran dalam Matius 7:24-29, dilakukan melalui uji validitas dan relibilitas yang ditunjukan/diujicobakan kepada siswa/i SMP Negeri 12 Kota Kupang, khusunya kelas IX G sebanyak 30 orang/responden.

Adapun hasil Iterasi Ortogonal variabel Metode Pembelajaran Berdasarkan Matius 7 : 24-29 tampak pada tabel dibawah ini :

\begin{tabular}{|c|c|c|c|}
\hline $\begin{array}{l}\text { No. } \\
\text { Item }\end{array}$ & $\mathbf{r}_{\text {hitung }}$ & $\mathbf{r}_{\text {tabel }}$ & Status \\
\hline 1 & 0,520 & 0,361 & Valid \\
\hline 2 & 0,627 & 0,361 & Valid \\
\hline 3 & 0,541 & 0,361 & Valid \\
\hline 4 & 0,444 & 0,361 & Valid \\
\hline 5 & 0,664 & 0,361 & Valid \\
\hline 6 & 0,665 & 0,361 & Valid \\
\hline 7 & 0,406 & 0,361 & Valid \\
\hline 8 & 0,557 & 0,361 & Valid \\
\hline 9 & 0,662 & 0,361 & Valid \\
\hline 10 & 0,567 & 0,361 & Valid \\
\hline 11 & 0,347 & 0,361 & Tidak Valid \\
\hline 12 & 0,527 & 0,361 & Valid \\
\hline 13 & 0,653 & 0,361 & Valid \\
\hline 14 & 0,247 & 0,361 & Tidak Valid \\
\hline 15 & 0,380 & 0,361 & Valid \\
\hline 16 & $.0,467$ & 0,361 & Valid \\
\hline 17 & 0,454 & 0,361 & Valid \\
\hline 18 & 0,459 & 0,361 & Valid \\
\hline 19 & 0,510 & 0,361 & Valid \\
\hline 20 & 0,476 & 0,361 & Valid \\
\hline 21 & 0,352 & 0,361 & Tidak Valid \\
\hline 22 & 0,517 & 0,361 & Valid \\
\hline 23 & 0,569 & 0,361 & Valid \\
\hline 24 & 0,450 & 0,361 & Valid \\
\hline 25 & 0,453 & 0,361 & Valid \\
\hline 26 & 0,541 & 0,361 & Valid \\
\hline 27 & 0,251 & 0,361 & Tidak Valid \\
\hline 28 & 0,371 & 0,361 & Valid \\
\hline 29 & 0,519 & 0,361 & Valid \\
\hline 30 & 0,362 & 0,361 & Valid \\
\hline
\end{tabular}

12 Syaifuddin Anwar, Reliabilitas Dan Validitas (Yogyakarta: Pustaka Pelajar, 2003). 
Hasil perhitungan iterasi ortogonal untuk variabel $\mathrm{X}$ (metode pembelajaran) diatas menunjukan dari 30 butir instrumen setelah uji coba doperoleh 26 butir valid dan 4 butir drop. Dengan demikian berarti terdapat 26 butir sebagai instrumen valid untuk diedarkan ke sampel penelitian.

Untuk uji relibilitas instrumen dalam melihat dalam konsistensi jawaban yang diberikan dianalisis dengan menggunakan koefisiensi Alpha Cronbach. Koefisiensi relibilitas variabel metode pembelajaran dengan jumlah butir valid sebanyak 26, didapatkan indeks relibilitas sebesar 0,749. Nilai $r_{\text {tabel }}$ sebesar 0,361. Nilai $r_{\text {tabel }}$ pada taraf singnifikan $5 \%$ dengan jumlah responden 30 dan $\mathrm{df}=\mathrm{N}-2$ $=28$ diperoleh angka 0,374. Karena nilai Cronbach's Alpha > dari $\mathrm{r}_{\text {tabel }}$ maka disampaikan bahwa construct pernyataan dari variabel $\mathrm{X}$ terbukti reliabel. Dengan demikian instrumen yang digunakan dalam penelitian ini valid dan reliabel.

Data yang diperoleh dari hasil penelitian dianalisis dengan teknik statistik menggunakan aplikasi SPSS Versi 23 dengan proses analisa antara lain: Analisis Deskriptif, Uji Persyaratan Analisis dalam hal ini uji normalitas dan uji linearitas, kemudian dilakukan Uji Hipotesis yang dilanjutkan dengan penarikan kesimpulan.

\section{Hasil dan pembahasan}

\section{Hasil Penelitian \\ Deskripsi Data}

Hasil penelitian yang diperoleh melalui tabulasi angket diuraikan dalam deskripsi data. Deskripsi data tersebut penulis disajikan berdasarkan masingmasing indikator, yaitu variabel Metode Pembelajaran berdasarkan Matius 7:24-29 (variabel X) dan analisis penelitian dari variabel Hasil Belajar Siswa (Variabel Y).

\section{Deskripsi Variabel X "Metode Pembelajaran berdasarkan Matius 7:24-29"}

Berdasarkan tabulasi data dari 30 sampel penelitian ditemukan nilai mean sebesar 86,90, nilai median sebesar 86,00, nilai sebesar mode 83 , nilai standar deviation sebesar 4,498, nilai variance sebesar 20,231, nilai range sebesar 16, nilai minimum sebesar 80 , nilai maximum sebesar 96 dan nilai sum sebesar 2607. Adapun output dari hasil perhitungan dengan SPSS versi 23 untuk statistic deskriptif tersebut dapat dilihat dalam tabel dibawah ini:

\section{Statistics}


Metode Pembelajara Berdasarkan Matius 7:24-29

\begin{tabular}{|c|c|}
\hline $\begin{array}{l}\text { N } \quad \text { Malid } \\
\text { Mean } \\
\text { Median } \\
\text { Mode } \\
\text { Std. Deviation } \\
\text { Range } \\
\text { Minimum } \\
\text { Maximum } \\
\text { Sum }\end{array}$ & $\begin{array}{r}30 \\
0 \\
86,9000 \\
86,0000 \\
83,00 \\
4,49789 \\
16,00 \\
80,00 \\
96,00 \\
2607,00\end{array}$ \\
\hline
\end{tabular}

Analisis data deskriptif pada Matius 7:24-29 di atas dapat juga dilihat variabel Metode pembelajaran berdasarkan dalam bentuk histogram sebagai berikut:

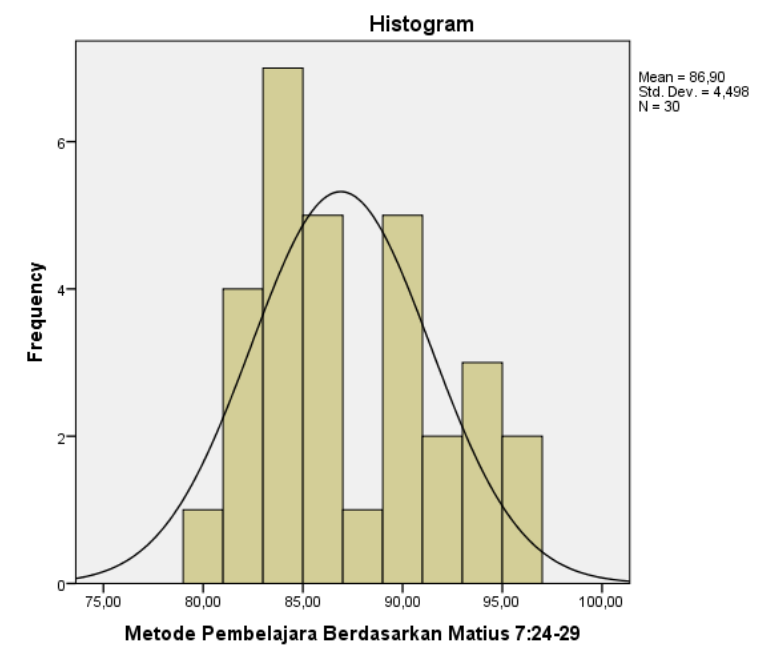

\section{Deskripsi Variabel Y “ Hasil Belajar Siswa”}

Berdasarkan tabulasi data dari 30 sampel penelitian pada variabel hasil belajar siswa, ditemukan nilai mean sebesar 85,07, nilai median sebesar 85,00, nilai mode sebesar 84, nilai standar deviation sebesar 3,039, nilai range sebesar
10, nilai minimum sebesar 80 , nilai maximum sebesar 90 dan nilai sum sebesar 2552. Adapun output dari hasil perhitungan dengan SPSS versi 23 untuk statistic deskriptif tersebut dapat dilihat dalam tabel dibawah ini:

\section{Statistics}

\begin{tabular}{|c|c|c|}
\hline \multicolumn{3}{|c|}{$\mathrm{N}$} \\
\hline & Missing & \\
\hline & & $\begin{array}{l}85,07 \\
85,00\end{array}$ \\
\hline & & $84^{a}$ \\
\hline & riation & 3,039 \\
\hline & & 10 \\
\hline
\end{tabular}


Analisis data deskriptif pada juga dilihat dalam bentuk histogram variabel Metode hasil belajar di atas dapat sebagai berikut:

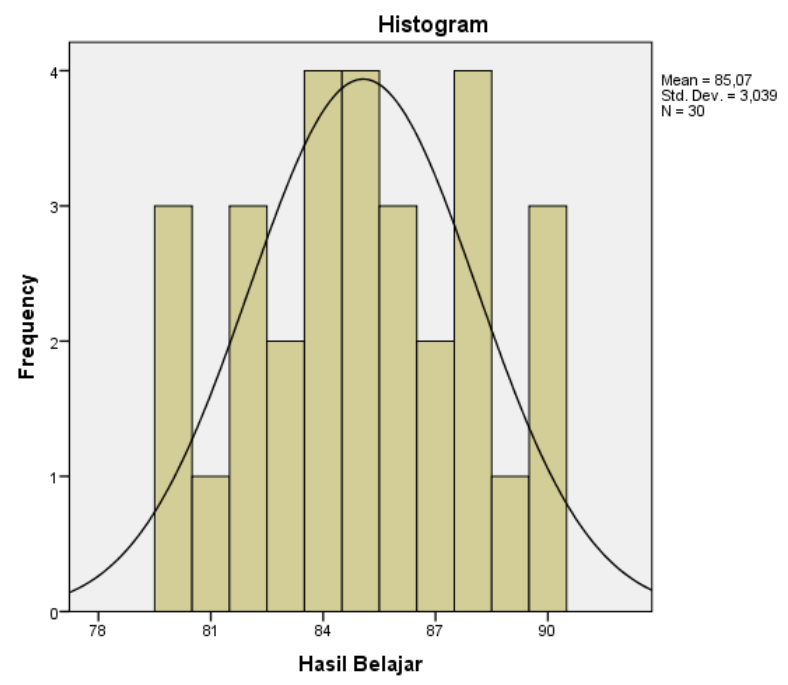

\section{Hasil Pengujian Hipotesis}

Dalam kaitannya dengan pengujian hipotesis penelitian yang ada, maka melalui tahap ini penulis melakukan Uji Persyaratan Analisis. Adapun uji persyaratan analisis yang dimaksud adalah uji normalitas dan uji linearitas.

\section{Uji Normalitas}

Secara umum Uji normalitas dilakukian dengan tujuan melihat apakah data dalam penelitian ini berdistribusi secara normal atau tidak normal. Data yang berdistribusi normal diperlukan karena pengujian hipotesis dengan model regresi dan korelasi (Jika data berdistribusi normal maka Pengujian dilakukan dengan statistik parametris) memprasyaratkan setiap variabel yang akan dianalisis berada pada berdistribusi Normal. ${ }^{13}$

Dalam pengujian Instrumen uji normalitas, penulis menggunakan kolmogorov-Smirnov, kemudian Kriteria normalitas yang dipakai adalah criteria dari santoso dan Tjiptono yaitu apabila Nilai sig atau signifikansi atau nilai probalitas lebih

${ }^{13}$ Sugiyono, Metode Penelitian Kombinasi, 228. 
kecil dari 0,5 $(<0,05)$ maka distribusi data adalah tidak normal dan jika nilai sig atau signifikansi atau nilai probalitas lebih besar dari $0,5(>0,05)$ maka data tersebut berdistribusi secara normal. ${ }^{14}$

Pengujian normalitas data pada masing-masing variabel diperoleh hasil sebagai berikut: untuk distribusi data variabel Metode pembelajaran berdasarkan Matius 7:24-29 dan variabel $\mathrm{Y}$ yaitu hasil belajar siswa di SMP Negeri 12 Kota
Kupang diperoleh nilai signifikansi pada uji kolmogorov-smirnov sebesar 0,102 (Variabel X) dan 0,200 (Variabel Y) dengan demikian signifikansi kedua variabel >0,05 artinya baik variabel Metode pembelajaran berdasarkan Matius 7:24-29 maupun variabel hasil belajar siswa di SMP Negeri 12 Kota Kupang berdistribusi secara Normal. Hasil Uji normalitas data dapat dilihat pada tabel berikut:

Tests of Normality

\begin{tabular}{|l|r|r|r|r|r|r|}
\hline & \multicolumn{3}{|c|}{ Kolmogorov-Smirnov } & \multicolumn{3}{c|}{ Shapiro-Wilk } \\
\cline { 2 - 7 } & Statistic & \multicolumn{1}{c|}{ df } & \multicolumn{1}{c|}{ Sig. } & \multicolumn{1}{c|}{ Statistic } & \multicolumn{1}{c|}{ df } & \multicolumn{1}{c|}{ Sig. } \\
\hline $\begin{array}{l}\text { Metode pembelajaran } \\
\text { berdasarkan Matius 7:24- } \\
29\end{array}$ &, 146 & 30 &, 102 &, 941 & 30 &, 095 \\
$\begin{array}{l}\text { Hasil Belajar siswa di } \\
\text { SMP Negeri 12 Kota } \\
\text { Kupang }\end{array}$ &, 099 & 30 &, $200^{*}$ &, 956 & 30 &, 243 \\
\hline
\end{tabular}

*. This is a lower bound of the true significance.

a. Lilliefors Significance Correction

Hasil pengujian tersebut dapat juga dilihat grafik normal plot. Pada grafik ini terlihat bahwa data berada dalam toleransi normal, demikian juga detrended-nya tidak menunjukkankurva sinus.

14 Singgih Santoso and Fandy Tjiptono, Reset Pemasaran Dan Aplikasi Dengan SPSS (Jakarta: Exel Media Komputindo, 2001), 134. 
Volume 1

Edisi 1
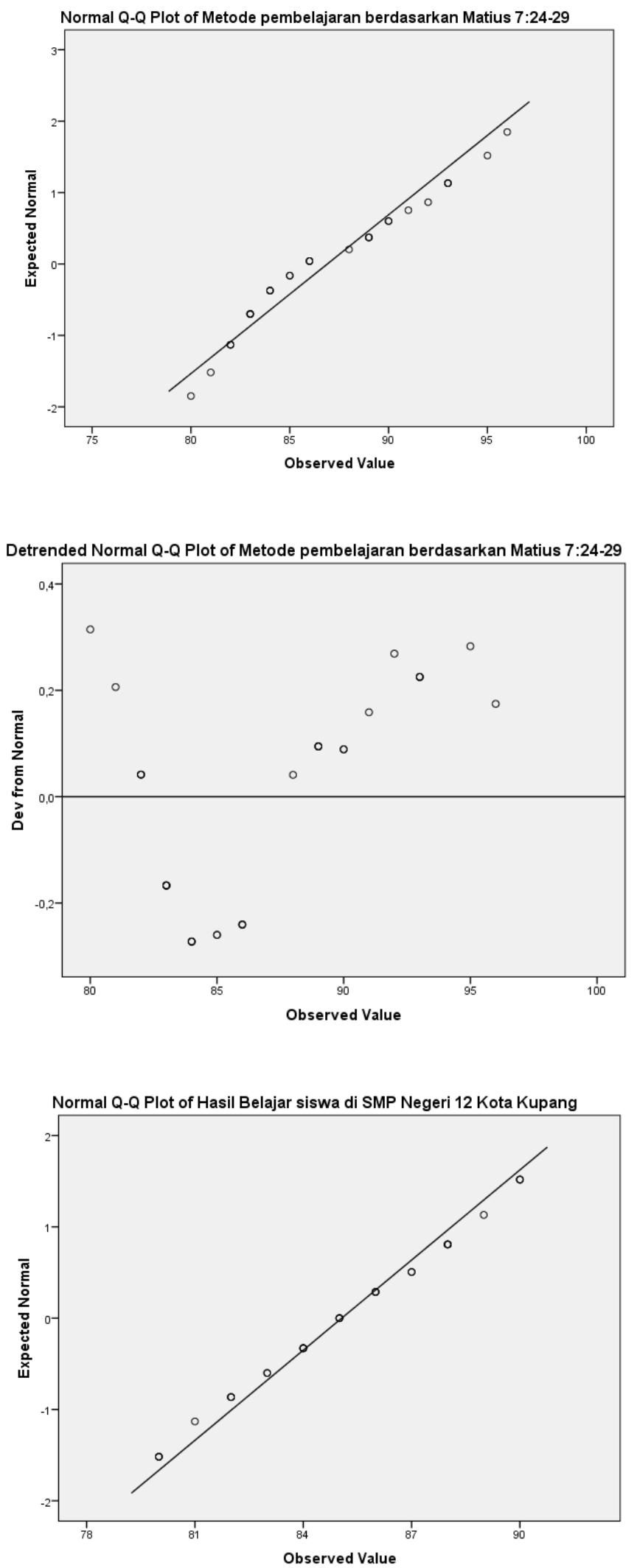


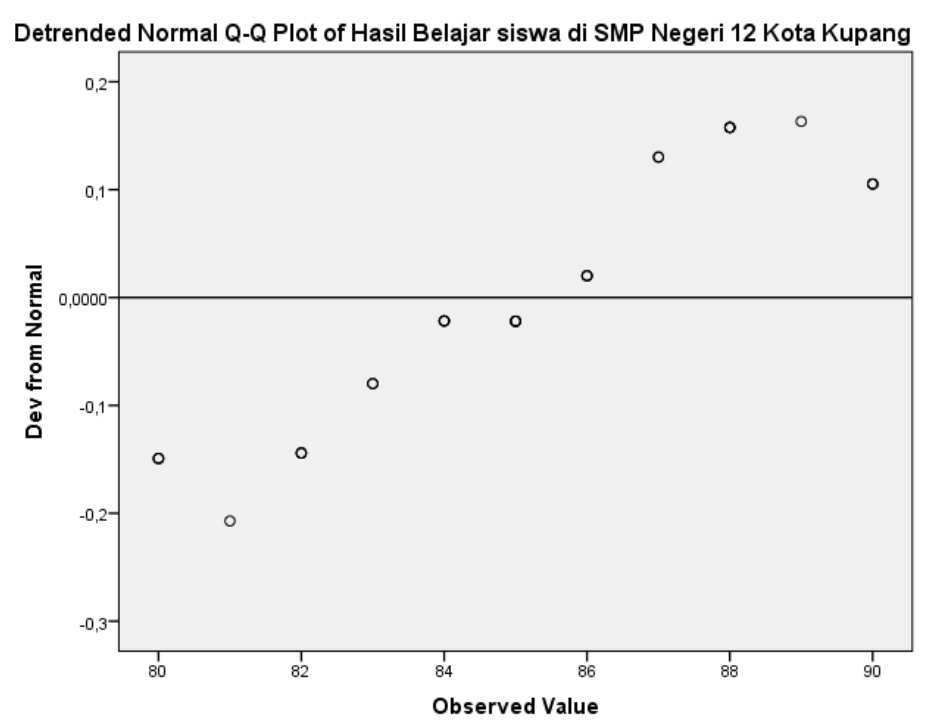

\section{Uji Linearitas}

Dalam Uji linearitas penelitian ini dilakukan dengan menggunakan test for linearity pada taraf signifikan 0,05. Untuk uji linearitas, dua variabel dikatakan linear bila signifikansi pada baris deviation from linearity >dari 0,05.

Uji linearitas dilakukan dengan analisis regresi antara Metode pembelajaran berdasarkan Matius 7:24-29 dengan hasil belajar siswa di SMP Negeri 12 Kota Kupang. Hasil uji linearitas analisis regresi residu $\mathrm{X}$ terhadap $\mathrm{Y}$, dihasilkan sebesar 1,454 adalah signifikan pada $\alpha=0,242,(\alpha>0,05)$. Artinya hubungan antara X terhadap Y adalah Linear.

\section{ANOVA Table}

\begin{tabular}{|c|c|c|c|c|c|c|c|}
\hline & & & $\begin{array}{l}\text { Sum of } \\
\text { Squares }\end{array}$ & Df & $\begin{array}{l}\text { Mean } \\
\text { Square }\end{array}$ & $F$ & Sig. \\
\hline \multirow{5}{*}{$\begin{array}{l}\text { Hasil Belajar } \\
\text { siswa di SMP } \\
\text { Negeri } 12 \text { Kota } \\
\text { Kupang * Metode } \\
\text { pembelajaran } \\
\text { berdasarkan } \\
\text { Matius 7:24-29 }\end{array}$} & \multirow{3}{*}{$\begin{array}{l}\text { Between } \\
\text { Groups }\end{array}$} & (Combined) & 149,867 & 14 & 10,705 & 1,361 & ,280 \\
\hline & & Linearity & 1,135 & 1 & 1,135 & ,144 & ,709 \\
\hline & & $\begin{array}{l}\text { Deviation from } \\
\text { Linearity }\end{array}$ & 148,732 & 13 & 11,441 & 1,454 & ,242 \\
\hline & \multicolumn{2}{|c|}{ Within Groups } & 118,000 & 15 & 7,867 & & \\
\hline & \multicolumn{2}{|l|}{ Total } & 267,867 & 29 & & & \\
\hline
\end{tabular}

\section{Uji Hipotesis}

Hipotesis yang akan diuji dalam pengaruh Metode pembelajaran berdasarkan kitab Matius 7:24-29, penelitian ini yaitu "diduga terdapat 
terhadap hasil belajar siswa di SMP Negeri

12 Kota Kupang.”
Berdasarkan hasil pengolahan data diperoleh output dari aplikasi SPSS versi 23 seperti berikut:

Model Summary

\begin{tabular}{|l|r|r|r|r|}
\hline Model & $\mathrm{R}$ & R Square & $\begin{array}{c}\text { Adjusted R } \\
\text { Square }\end{array}$ & $\begin{array}{c}\text { Std. Error of the } \\
\text { Estimate }\end{array}$ \\
\hline 1 &, $065^{\mathrm{a}}$ &, 040 &,- 031 & 3,086 \\
\hline
\end{tabular}

a. Predictors: (Constant), Metode pembelajaran berdasarkan Matius 7:24-29

Berdasarkan hasil analisis pada table di atas ditemukan $R$ Square sebesar 0,04 dari koefisien korelasi 0,065. $R$ Square biasa juga disebut dengan koefisien determinasi yang berarti bahwa pada penelitian ini ada $40 \%$ dari hasil belajar siswa di SMP Negeri 12 Kota Kupang dapat dijelaskan oleh variabel Metode

$$
\begin{array}{ll}
\mathrm{Y} & =\text { Nilai yang diprediksikan } \\
\mathrm{a} & =\text { Konstanta atau bila } \mathrm{X}=0 \\
\mathrm{~b} & =\text { Koefisien korelasi } \\
\mathrm{X} & =\text { Nilai Variabel independen }{ }^{15}
\end{array}
$$

pembelajaran berdasarkan kitab Matius 7:24-29 sedangkan sisanya dapat dijelaskan oleh variabel lain atau faktorfaktor lain yang belum diteliti.

Secara umum persamaan regresi sederhana dapat dirumuskan dengan $\mathrm{Y}=\mathrm{a}+\mathrm{b} \mathrm{X}$ dimana:

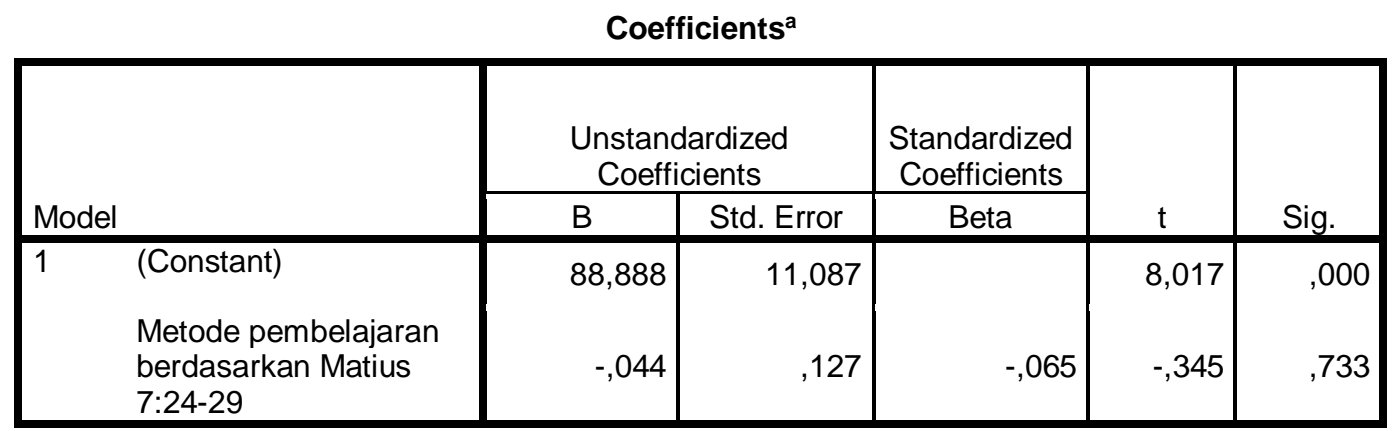

a. Dependent Variable: Hasil Belajar siswa di SMP Negeri 12 Kota Kupang

Pada table coefficients di atas menunjukkan nilai sig. adalah 0,000 $(<0,05)$ dengan demikian nilai $\mathrm{B}(88,888)$ adalah signifikan. Oleh karena itu persamaan regresi yang tepat untuk variabel metode pembelajaran Matius 7:24-29 dan variabel Hasil belajar siswa adalah:

$$
Y=88,888+0,004 X
$$

\footnotetext{
${ }^{15}$ Sugiyono, Metode Penelitian Kombinasi, 247.
} 
Dengan $\quad X=$ Metode pembelajaran

berdasarkan kitab Matius 7:24-29

$\mathrm{Y}=$ Hasil belajar siswa di SMP

Negeri 12 Kota Kupang dari persamaan tersebut dapat diinterpretasi bahwa jika indicator Metode pembelajaran berdasarkan kitab Matius 7:24-29 mengalami kenaikan 1 poin maka Hasil belajar siswa di SMP Negeri 12 Kota Kupang akan mengalami peningkatan sebesar 0,004 kali. Konstanta sebesar 88,888 artinya jika Metode pembelajaran berdasarkan kitab Matius 7:24-29 adalah 0 maka Hasil belajar siswa di SMP Negeri 12 Kota Kupang adalah 88,888

Adapun hipotesis statistik yang diuji dalam penelitian ini adalah:

$\mathrm{H}_{0} \quad$ : Tidak ada pengaruh Metode pembelajaran berdasarkan kitab Matius 7:24-29, terhadap hasil belajar siswa di SMP Negeri 12 Kota Kupang.

$\mathrm{H}_{1}$ : Terdapat pengaruh Metode pembelajaran berdasarkan kitab Matius 7:24-29, terhadap hasil belajar siswa di SMP Negeri 12 Kota Kupang

Pada hasil analisis yang terlihat dalam output SPSS pada table coefficient ditemukan $\mathrm{t}$ hitung $=8.017$ dengan nilai signifikansi $0,000<0,05$, maka $\mathrm{H}_{0}$ ditolak dan $\mathrm{H}_{1}$ diterima yang berarti terdapat pengaruh yang signifikan variabel Metode pembelajaran berdasarkan kitab Matius 7:24-29, terhadap hasil belajar siswa di SMP Negeri 12 Kota Kupang

Dengan demikian hipotesis yang menyatakan bahwa Ada pengaruh yang signifikan variabel Metode pembelajaran berdasarkan kitab Matius 7:24-29 (X), terhadap hasil belajar siswa di SMP Negeri 12 Kota Kupang(Y) terbukti dalam penelitian ini.

\section{Pembahasan}

Berdasarkan hasil perhitungan uji persyaratan analisis regresi sederhana dengan menggunakan SPSS didapatkan hasil uji normalitas (Kolomogorovsmirnov) untuk variabel Metode pembelajaran berdasarkan kitab Matius 7:24-29 sebesar 0,102 dan pada variabel Hasil belajar siswa di SMP Negeri 12 Kota Kupang 0,200, karena asumsi signifikannya lebih besar dari 0,05 maka data variabel Metode pembelajaran berdasarkan kitab Matius 7:24-29 sebesar maupun variabel Hasil belajar siswa di SMP Negeri 12 Kota Kupang adalah berdistribusi normal. Berdasarkan perhitungan uji Linearitas regresi diperoleh F hitung 1.454 dengan signifikansi sebesar 0,242, oleh karena signifikansinya lebih besar dari 0,05 $(>0,05)$ maka dari variabel 
Metode pembelajaran berdasarkan kitab Matius 7:24-29 (X) dengan variabel Hasil belajar siswa di SMP Negeri 12 Kota Kupang (Y) memiliki hubungan linear.

Berdasarkan hasil analisis dalam penelitian ini menunjukkan adanya pengaruh positif antara Metode pembelajaran berdasarkan kitab Matius 7:24-29 dengan Hasil belajar siswa di SMP Negeri 12 Kota Kupang, diperoleh $\overline{\mathrm{Y}}=$ $88,888+0,004 \mathrm{X}$ (dari persamaan segresi sederhana yaitu $\mathrm{Y}=\mathrm{a}+\mathrm{b} \mathrm{X}$ ) yang artinya setiap satu poin skor pada variabel Metode pembelajaran berdasarkan kitab Matius 7:24-29 mempengaruhi Hasil belajar siswa di SMP Negeri 12 Kota Kupang sebesar 0,004 kali. Konstanta sebesar 88,888 artinya jika Metode pembelajaran berdasarkan kitab Matius 7:24-29 adalah 0 maka Hasil belajar siswa di SMP Negeri 12 Kota Kupang adalah 88,888. Sehingga dapat dikatakan bahwa jika Metode pembelajaran berdasarkan kitab Matius 7:24-29 dimaksimalkan dengan indicatorindikator yang ada didalamnya maka akan semakin besar pengaruhkan pada Hasil belajar siswa di SMP Negeri 12 Kota Kupang.

Dari perhitungan koefisien determinansi diketahui bahwa Hasil belajar siswa di SMP Negeri 12 Kota Kupang dipengaruhi oleh Metode pembelajaran berdasarkan kitab Matius 7:24-29 sebesar $40 \%$ dan selebihnya dipengaruhi oleh faktor-faktor lain diluar faktor Metode pembelajaran berdasarkan kitab Matius 7:24-29 yang belum diteliti oleh penulis.

Berdasar hasil penelitian ini dan dari beberapa penelitian sebelumnya dapat disimpulkan bahwa metode pembelajaran yang dilakukan Yesus ketika berkhotbah atau mengajar masih relevan untuk digunakan pada masa kini.

\section{Kesimpulan}

Dari hasil penelitian ini dapat disimpulkan bahwa terdapat pengaruh penerapan Metode Pembelajaran yang dipakai Yesus Dalam Matius 7:24-29 Terhadap Hasil Belajar Siswa Di SMP Negeri 12 Kota Kupang sebesar 40\%. Oleh karena itu penulis menyarankan supaya Guru PAK harus belajar dari Yesus sebagai Guru Agung bagaimana Ia memilih metode yang sesuai dengan kebutuhan pendengarnya. Guru PAK juga harus selektif dalam menggunakan metode yang sesuai dengan kebutuhan siswa, sehingga hasil belajar yang diharapkan dapat tercapai. Selain itu guru PAK harus meningkatkan kompetensi yang dimiliki karena guru merupakan perancang pengajaran, pengelola pengajaran, dan sebagai penilai pengajaran, sehingga peran guru menjadi sangat penting. 


\section{Referensi}

Agung, Imanuel, and Made Astika. "Penerapan Metode Mengajar Yesus Menurut Injil Sinoptik Dalam Pelaksanaan Pendidikan Agama Kristen Di SMA Gamaliel Makassar." Jurnal Jaffray 9, no. 2 (October 1, 2011): 147-171. Accessed May 30, 2020. https://ojs.sttjaffray.ac.id/JJV71/art icle/view/99.

Anwar, Syaifuddin. Reliabilitas Dan Validitas. Yogyakarta: Pustaka Pelajar, 2003.

Kristiani, Dina. "IMPLEMENTASI MODEL TEACHING LEARNING TUHAN YESUS MENURUT INJIL MATIUS TERHADAP GURU-GURU PENDIDIKAN AGAMA KRISTEN DI KOTA SURAKARTA." REGULA FIDEI: Jurnal Pendidikan Agama Kristen 3, no. 1 (2018): 1-21. Accessed May 30, 2020. http://christianeducation.id/ejournal/index.php/regulafidei/articl e/view/16.

Kuhns, Janet. "Mengajar Secara Kreatif." Jurnal Jaffray 1, no. 1 (January 5, 2005): 90-100. Accessed May 30, 2020.

https://ojs.sttjaffray.ac.id/JJV71/art icle/view/171.

Lilo, Deflit Dujerslaim. "Presuposisi dan Metode Yesus dalam Menyampaikan Pendapat: Sebuah Pedoman bagi Para Akademisi." BIA': Jurnal Teologi dan Pendidikan Kristen Kontekstual 2, no. 1 (June 26, 2019): 121-138. Accessed May 30, 2020. http://www.jurnalbia.com/index.ph $\mathrm{p} / \mathrm{bia} /$ article/view/86.
Nuhamara, Daniel. Pembimbing PAK. Bandung: Jurnal Info Media, 2007.

Rantesalu, Marsi Bombongan. GURU PENDIDIKAN AGAMA KRISTEN SEBAGAI PELOPOR REVOLUSI MENTAL. Preprint. AgriXiv, October 14, 2019. Accessed January 21, 2020. https://osf.io/576qt.

Singgih Santoso, and Fandy Tjiptono. Reset Pemasaran Dan Aplikasi Dengan SPSS. Jakarta: Exel Media Komputindo, 2001.

Sinlae, Ronald Yohanes. "Kompetensi Pedagogik Tuhan Yesus dalam Injil Matius Pasal 5-7." Excelsis Deo: Jurnal Teologi, Misiologi, dan Pendidikan 4, no. 1 (December 31, 2019): 35-55. Accessed May 30, 2020. http://ejournal.sttexcelsius.ac.id/index.php /excelsisdeo/article/view/15.

Sugiyono. Metode Penelitian Kombinasi. Bandung: Alfabeta, 2015.

Tafonao, Talizaro. "Yesus Sebagai Guru Teladan Dalam Masyarakat Berdasarkan Perspektif Injil Matius." Khazanah Theologia 2, no. 1 (April 30, 2020): 52-60. Accessed May 30, 2020. https://journal.uinsgd.ac.id/index.p $\mathrm{hp} / \mathrm{kt} /$ article/view/8390.

Wahono, Wismoady. Disini Ku Temukan. Jakarta: BPK Gunung Mulia, 2015. 